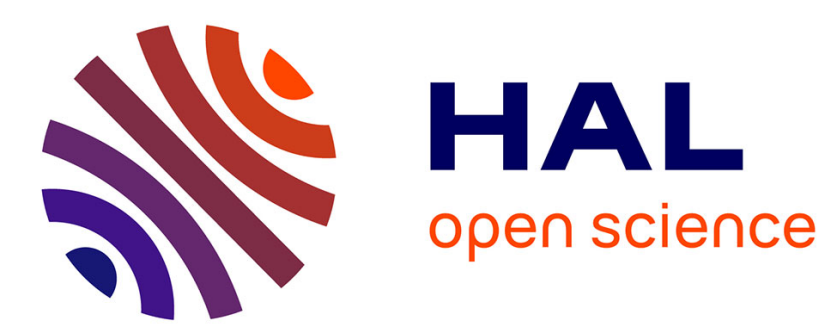

\title{
Highly Selective Syn Addition of 1,3-Diones to Internal Ynamides Catalyzed by Zinc Iodide
}

\author{
Rémi Plamont, Lionel V. Graux, Hervé Clavier
}

\section{To cite this version:}

Rémi Plamont, Lionel V. Graux, Hervé Clavier. Highly Selective Syn Addition of 1,3-Diones to Internal Ynamides Catalyzed by Zinc Iodide. European Journal of Organic Chemistry, 2018, 2018 (11), pp.1372-1376. 10.1002/ejoc.201701690 . hal-01768371

\section{HAL Id: hal-01768371 \\ https://hal.science/hal-01768371}

Submitted on 18 Apr 2018

HAL is a multi-disciplinary open access archive for the deposit and dissemination of scientific research documents, whether they are published or not. The documents may come from teaching and research institutions in France or abroad, or from public or private research centers.
L'archive ouverte pluridisciplinaire HAL, est destinée au dépôt et à la diffusion de documents scientifiques de niveau recherche, publiés ou non, émanant des établissements d'enseignement et de recherche français ou étrangers, des laboratoires publics ou privés. 


\title{
Highly selective syn addition of 1,3-diones to internal ynamides catalyzed by zinc iodide
}

\author{
Rémi Plamont, ${ }^{[a]}$ Lionel V. Graux, ${ }^{[a]}$ and Hervé Clavier*[a] \\ Dedication ((optional))
}

\begin{abstract}
Having previously established that 1,3-diones could be used as nucleophiles to perform additions to ynamides, highly selective hydroalkoxylation of internal ynamides is now described herein. Several catalytic systems were compared to carry out this transformation including transition metal-based catalysts or Lewis acids. $\mathrm{Znl}_{2}$ was found to be both very active and highly selective giving only $E$ adducts through a syn addition. Scope and limits investigation showed that this catalyst was compatible with various functional groups. In addition to 17 examples of ynamide hydroalkoxylation, one example of ynamide hydroarylation is reported.
\end{abstract}

\section{Introduction}

Among the myriad of reactions using ynamides as substrate, ${ }^{[1]}$ those consisting of the heteronucleophile introduction to the ynamide $\alpha$-carbon are particularly interesting from a synthetic point of view. Thus, according to the nature of the nucleophile, as well as the pending functional groups of the ynamides, various structurally different products can be formed. With oxygen nucleophiles, various reactions can be performed ${ }^{[2-4]}$ such as the hydration of ynamide that can be achieved under acid conditions to straightforwardly give rise to functionalized amides. ${ }^{[5]}$ Skrydstrup even reported a gold-catalyzed hydration of dimerized ynamides leading to the formation of 2,5-diamidofurans. ${ }^{[6]}$ Subsequently to Lam's report on palladium-catalyzed hydroacyloxylation of ynamide, ${ }^{[7]}$ it was demonstrated that the addition of carboxylic acids could be performed without catalyst. ${ }^{[5 b, 8]}$

In comparison to the previously cited reactions, the hydroalkoxylation of ynamides has been less studied whereas it represents a straightforward access to unprecedented alkoxysubstituted enamide patterns. Unfortunately with simple alcohols, such as benzyl alcohol, hydroalkoxylation was unsuccessful. ${ }^{[9,10]}$ Hsung disclosed that with allylic ${ }^{[11]}$ and propargylic alcohols ${ }^{[12]}$ the hydroalkoxylation was possible using a substoichiomietric amount of $p$-nitrobenzenesulfonic acid under thermal activation. However, since [3,3]-sigmatropic rearrangements took place, only the corresponding amides were isolated. ${ }^{[13]}$ Very recently, Swamy reported a single example of hydroxyalkylation of an ynamide with phenol using a palladium-based catalyst and a base upon thermal activation. ${ }^{[14]}$ Unfortunately, the stereochemistry of the carboncarbon double bond was not clearly discussed (Scheme 1.a). During the course of our research directed toward the use of

[a] Aix Marseille Univ., CNRS, Centrale Marseille, iSm2, Marseille, France

E-mail: herve.clavier@univ-amu.fr

Supporting information for this article is given via a link at the end of the document. ynamides in $[2+1]$ cycloadditions, ${ }^{[15]}$ we discovered that Herrmann-Beller catalyst (H-B cat) was able to promote the hydroalkoxylation of ynamides with 1,3-diones. ${ }^{[16]}$ Although good yields were obtained with terminal ynamides (Scheme 1.b), the resulting products were easily hydrolysable under acid conditions. With internal ynamides, alkoxy-substituted enamide adducts were significantly more stable to acid conditions but their preparation led to mixtures of $E$ - and Z-isomers in low to moderate ratios (Scheme 1.c).

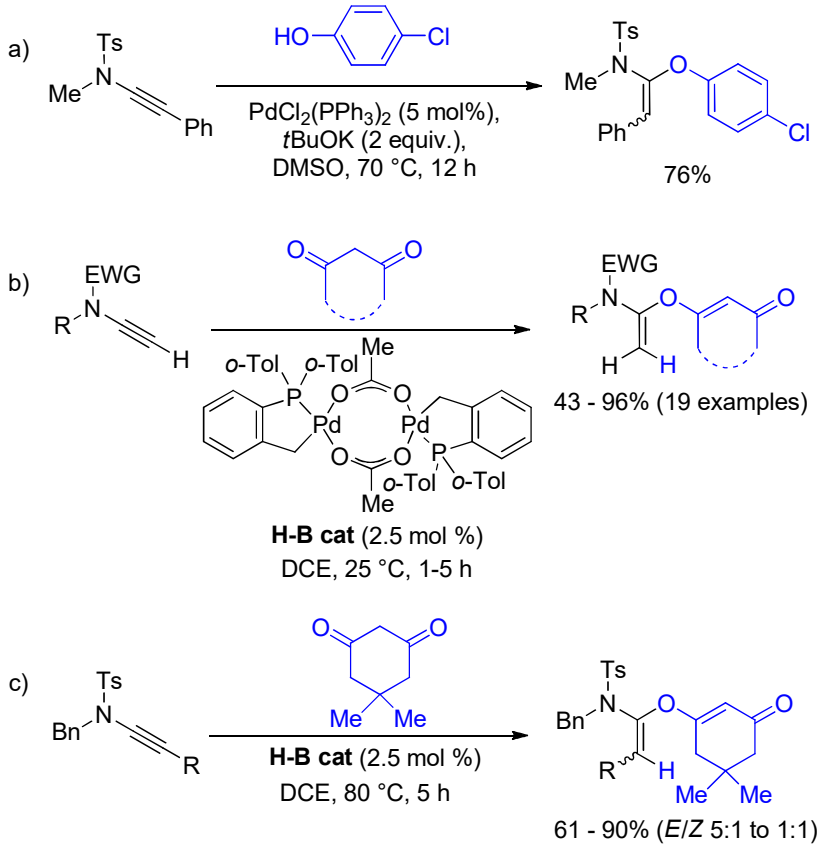

Scheme 1. Hydroalkoxylation reactions of ynamides affording alkoxysubstituted enamides.

To investigate the synthetic potential of alkoxy-substituted enamides, ${ }^{[8 b, 17]}$ the hydroalkoxylation adducts from internal ynamides represent more interesting substrates due to their higher stability. Nevertheless, it would be better to obtain them as single isomer. Therefore, we decided to further investigate the addition of 1,3-diones to internal ynamides with the primary objective of developing a highly selective catalytic system promoting this reaction.

\section{Results and Discussion}

We started to survey various catalytic systems using as benchmark substrates methyl-substituted ynamide $\mathbf{1 a}$ and dimedone $2 \mathbf{a}$ (Table 1 ). In the absence of catalyst, the reaction required a heating at $80{ }^{\circ} \mathrm{C}$ in dichoroethane (DCE) to observe 
the adduct formation (entries 1 and 2). Despite a good $E / Z$ ratio (19:1), the reaction required a prolonged heating time to reach a moderate yield. The use of the Herrmann-Beller catalyst (H-B cat) allowed the decrease of the reaction temperature, but only poor $E / Z$ selectivities were observed (entries 3 and 4$)$. With the gold complex $\left[\mathrm{Au}\left(\mathrm{PPh}_{3}\right) \mathrm{NTf}_{2}\right]$, the addition proceeded at lower temperature $\left(40^{\circ} \mathrm{C}\right.$, entry 5$)$ but despite a long reaction time $(16$ h), the yield of 3 aa was disappointing $(45 \%)$. At higher temperature, the gold catalyst showed a better efficiency but in detriment of the $E / Z$ selectivity (entry 6$).{ }^{[18]}$ Alternatively, we investigated several Lewis acids in order to efficiently activate the ynamide or/and the 1,3-dione. ${ }^{[19]} \ln (\mathrm{OTf})_{3}$ and $\mathrm{Sn}(\mathrm{OTf})_{2}$ were found very active with a complete conversion in $1 \mathrm{~h}$ at $25^{\circ} \mathrm{C}$ but low selectivities were obtained (entries 7 and 8). Copper(I) or (II) triflate slightly increased the $E / Z$ selectivity (around $10: 1$, entries 9 and 10). Whereas $\mathrm{Zn}(\mathrm{OTf})_{2}$ gave only a moderate selectivity (5.8:1, entry 11), $\mathrm{ZnCl}_{2}$ or $\mathrm{ZnBr}_{2}$ both allowed a substantial increase of the $E / Z$ selectivity (around 25:1, entries 12 and 13) with a comparable efficiency. Finally, in presence of zinc(II) iodide, we were able to successfully achieve the addition at $25^{\circ} \mathrm{C}$ in $1 \mathrm{~h}$ to give rise to exclusively $E$-adduct 3aa $(E / Z>50: 1)$ in $77 \%$ yield (entry 14). Concerning the difference of selectivies observed as a function of the zinc salt used, we assume that the halide or pseudohalide dissociation is favored in the case of $\mathrm{Znl}_{2}$ and might lead to the formation of chelate intermediates with reaction partners that trigger the exclusive syn addition of 1,3-dione $\mathbf{2} \mathbf{a}$.

Table 1. Optimization of the reaction conditions ${ }^{[a]}[20]$

\begin{tabular}{|c|c|c|c|c|c|}
\hline & 1a & & & & \\
\hline Entry & Catalyst & $\mathrm{T}\left({ }^{\circ} \mathrm{C}\right)$ & $\begin{array}{l}\text { Time } \\
\text { (h) }\end{array}$ & $\begin{array}{l}\text { Yield } \\
(\%)\end{array}$ & $E / Z^{[b]}$ \\
\hline 1 & None & 60 & 5 & NR & - \\
\hline 2 & None & 80 & 16 & 61 & $19: 1$ \\
\hline 3 & H-B cat & 60 & 5 & 45 & $2: 1$ \\
\hline 4 & H-B cat & 80 & 5 & 66 & $2: 1$ \\
\hline 5 & {$\left[\mathrm{Au}\left(\mathrm{PPh}_{3}\right) \mathrm{NTf}_{2}\right]$} & 40 & 16 & 45 & $19: 1$ \\
\hline 6 & {$\left[\mathrm{Au}\left(\mathrm{PPh}_{3}\right) \mathrm{NTf}_{2}\right]$} & 60 & 5 & 58 & $0.8: 1$ \\
\hline 7 & $\ln (\mathrm{OTf})_{3}$ & 25 & 1 & 90 & 2.8:1 \\
\hline 8 & $\mathrm{Sn}(\mathrm{OTf})_{2}$ & 25 & 1 & 65 & $5.7: 1$ \\
\hline 9 & $\mathrm{Cu}(\mathrm{OTf})_{2}$ & 25 & 1 & 92 & $10.4: 1$ \\
\hline 10 & $\mathrm{Cu}(\mathrm{OTf}) \cdot \mathrm{C}_{6} \mathrm{H}_{6}$ & 25 & 1 & 91 & $11.6: 1$ \\
\hline 11 & $\mathrm{Zn}(\mathrm{OTf})_{2}$ & 25 & 1 & 80 & $5.8: 1$ \\
\hline 12 & $\mathrm{ZnCl}_{2}$ & 25 & 1 & 73 & $25: 1$ \\
\hline 13 & $\mathrm{ZnBr}_{2}$ & 25 & 1 & 68 & $27: 1$ \\
\hline 14 & $\mathrm{ZnI}_{2}$ & 25 & 1 & 77 & $>50: 1$ \\
\hline
\end{tabular}

[a] Reaction conditions: ynamide 1a (150 mg, $0.5 \mathrm{mmol})$, dimedone $2 \mathrm{a}$ (70 mg, $0.5 \mathrm{mmol}, 1$ equiv.), catalyst ( $5 \mathrm{~mol} \% ; 2.5 \mathrm{~mol} \%$ for dimeric $\mathrm{H}-\mathrm{B}$ cat), DCE (3 mL, $0.17 \mathrm{M})$. [b] Determined by ${ }^{1} \mathrm{H}$ NMR. NR $=$ No reaction.

The influence of the solvent was then investigated (Table 2). The reaction performed well in DCE, dichloromethane (DCM) and toluene with a complete selectivity in favor of the $E$ adduct (entries 1-3). The use of moderately coordinating solvents such as THF or dioxane led to a slight decrease of both reaction yields and selectivities (entries 4 and 5 ). With the strongly acetonitrile, the drop of the selectivity was even more drastic (entry 6$)$. No reaction occurred in DMF in spite of a prolonged reaction time $(5 \mathrm{~h}$, entry 7). These results, both in terms of efficiency and also selectivity, support the assumption of an ynamide activation by $\mathrm{Znl}_{2}$ and the formation of chelates with the reactants. Despite lower yield and E/Z ratio, the catalytic system was found compatible with $\mathrm{MeOH}$ and no product resulting from the competitive addition of $\mathrm{MeOH}$ was detected (entry 8).

Table 2. Solvent screening in $\mathrm{Znl}_{2}$-catalyzed addition of dimedone $\mathbf{2 a}$ to ynamide $1 \mathrm{a}^{[\mathrm{a}]}$

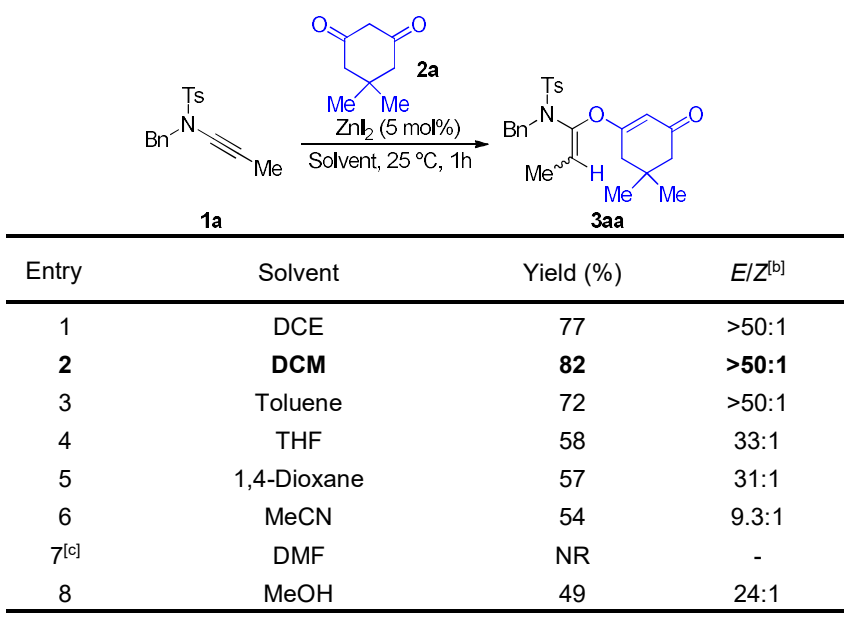

[a] Reaction conditions: ynamide $1 \mathrm{a}(150 \mathrm{mg}, 0.5 \mathrm{mmol})$, dimedone $2 \mathrm{a}$ (70 $\mathrm{mg}, 0.5 \mathrm{mmol}, 1$ equiv.), $\mathrm{Znl} 2$ ( $8 \mathrm{mg}, 0.025 \mathrm{mmol}, 5 \mathrm{~mol} \%$ ), solvent $(3 \mathrm{~mL}$, $0.17 \mathrm{M}), 25^{\circ} \mathrm{C}, 1 \mathrm{~h}$. [b] Determined by ${ }^{1} \mathrm{H}$ NMR. [c] $5 \mathrm{~h}$ of reaction. NR $=$ No reaction.

Having established the optimal reaction conditions, we further investigated the scope of the hydroalkoxylation with a range of 1,3-diones (Scheme 2). Similarly to dimedone $2 a$, the furyl derivate $\mathbf{2 b}$ gave rise rapidly to the $E$ isomer of adduct $\mathbf{3 a b}$ in a good yield. Owing to the poor solubility of the phenalene-1,3dione $2 \mathrm{c}$ at room temperature, the reaction mixture was heated at $40{ }^{\circ} \mathrm{C}$ for $5 \mathrm{~h}$ to reach a satisfactory yield of 3ac. 2-Substitued 1,3diones such $\mathbf{2 h}$ did not react despite an increase of reaction temperature to $40{ }^{\circ} \mathrm{C}$. Cyclopentane-1,3-dione based substrates $\mathbf{2 d}$ and $\mathbf{2 e}$ were good candidates affording the expected adducts in good yields and as $E$ isomers only. Unfortunately, indanedione 2i afforded a complex mixture of products. The $\mathrm{Znl}_{2}$-catalyzed addition was also efficiently achieved with Meldrum acid $2 \mathrm{f}$ or 4hydroxycoumarine $\mathbf{2 g}$. With $\mathbf{2} \mathbf{g}$, we obtained a separable mixture of compounds $\mathbf{3 a g}$ and $\mathbf{3} \mathbf{a g}$ ' in a 1.7:1 ratio resulting from the competitive addition of the two nucleophilic oxygen atoms. The main limitation of this transformation remained that only cyclic 1,3 diones can be used. 

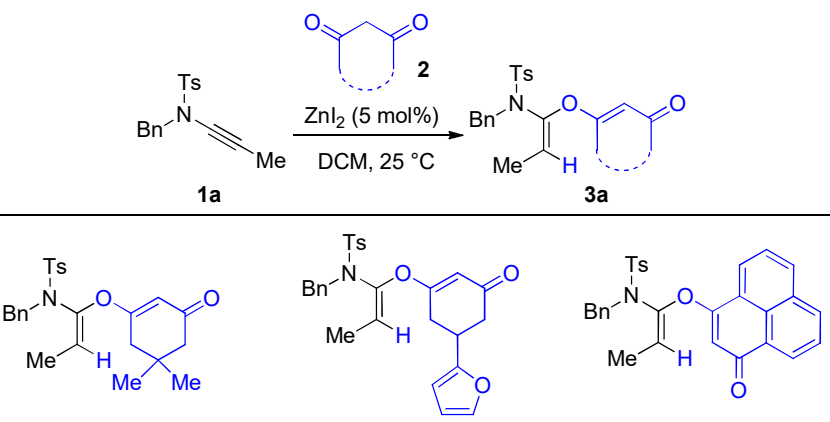

3 ac $-62 \%$

3aa - 82\%

(1 h, $E / Z>50: 1$ )

3ab - 76\%
$(1 \mathrm{~h}, E / Z>50: 1)$

(5 h at $40{ }^{\circ} \mathrm{C}, E / Z>50: 1$ )<smiles>C/C=C(/OC1=CC(=O)CC1)N(C)Cc1ccccc1</smiles>

3ad - $80 \%$ (2 h, $E / Z>50: 1$ )

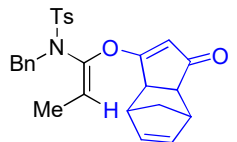

3ae - $77 \%$

(2 h, $E / Z>50: 1)$

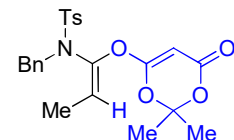

3 af $-83 \%$

(2 h, $E / Z>50: 1)$<smiles>CC=C(Oc1cc(=O)c2ccccc2o1)N(Cc1ccccc1)Cc1ccccc1</smiles>

3ag - $44 \%$

(5 h, $E / Z>50: 1)$

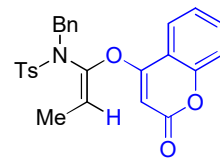

3ag' - $26 \%$

( $5 \mathrm{~h}, E / Z>50: 1)$

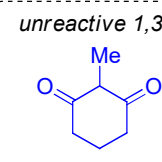

$2 \mathrm{~h}$

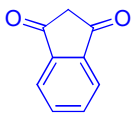

$2 \mathbf{i}$

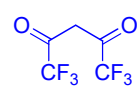

$2 \mathrm{j}$
Scheme 2. Scope investigation of the $\mathrm{Znl}_{2}$-catalyzed addition with various 1,3diones.

Results depicted in Scheme 3 showed that broad structural variations of the ynamide partner can be accommodated. Except in the case of the triisopropylsilyl-subsituted ynamide 1d, the nature of the ynamide substituent did not influenced the efficiency or selectivity outcomes of the additions. Corresponding adducts were isolated as $E$-isomers only. These included functionalized ynamides such as $\mathbf{1 e}, \mathbf{1 f}$ and $\mathbf{1 g}$ containing ester, nitrile and phtalimide groups respectively. For ynamides $1 \mathrm{~h}$ and $1 \mathrm{i}$ bearing nosyl and Boc (tert-butyloxycarbonyl) as electron withdrawing group respectively, $5 \mathrm{~h}$ of reaction were necessary to obtain moderate isolated yields but the addition remained exclusively syn. Oxazolidinone-substituted ynamides $\mathbf{1 j}$ and $\mathbf{1 k}$ were also found compatible with the reaction conditions and the corresponding $E$ adducts were isolated in moderate to good yields ( $66 \%$ and $78 \%$, respectively). Hydroalkoxylation of ynamide $1 \mathrm{k}$ bearing a bulky group $(t \mathrm{Bu})$ indicated that the absence of reactivity of $\mathbf{1 d}$ was probably due to electronic effects rather than a steric congestion.

Finally, we explored the possibility to expand this reaction to other nucleophiles. With the several catalytic systems investigated, phenols were found unreactive. As nitrogen,

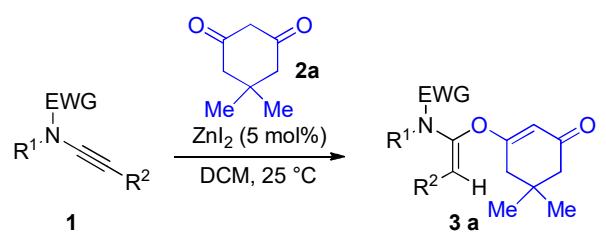<smiles>C/C=C(/OC1=CC(=O)CC(C)(C)C1)N(Cc1ccccc1)/C(=C/CCC)N(C)Cc1ccccc1</smiles>

3ba $-75 \%$

$(2 \mathrm{~h}, E / Z>50: 1)$

$(1 \mathrm{~h}, E / Z>50: 1)$<smiles>CN(Cc1ccccc1)C(=C[As])OC1=CC(=O)CC(C)(C)C1</smiles>

3da - Traces $(5 \mathrm{~h})$<smiles>CC1(C)CC(=O)C=C(O/C(=C/CCCN2C(=O)c3ccccc3C2=O)N(Cc2ccccc2)C(F)(F)F)C1</smiles>

$(5 \mathrm{~h}, E / Z>50: 1)$<smiles>CC1(C)CC(=O)C=C(OC(C)(C)C)C1</smiles><smiles>CCCCC=C(OC1=CC(=O)CC(C)(C)C1)N1CCOC1=O</smiles>

$3 \mathbf{j a}-66 \%$

$(3 \mathrm{~h}, E / Z>50: 1)$<smiles>CN(Cc1ccccc1)C(=CCOCC(=O)O)OC1=CC(=O)CC(C)(C)C1</smiles>

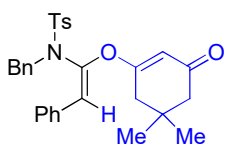

3 ca $-72 \%$

(3 h, $E / Z>50: 1)$<smiles></smiles>

$(3 \mathrm{~h}, E / Z>50: 1)$<smiles>C/C=C(/OC1=CC(=O)CC(C)(C)C1)N([NH-])Cc1ccccc1</smiles>

3ha $-56 \%$

$(5 \mathrm{~h}, E / Z>50: 1)$

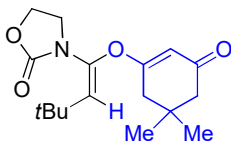

3ka - $78 \%$

$(5 \mathrm{~h}, E / Z>50: 1)$

Scheme 3. Scope investigation with various internal ynamides $\left(\mathrm{Ns}=\mathrm{SO}_{2}(p-\right.$ $\left.\mathrm{NO}_{2}-\mathrm{C}_{6} \mathrm{H}_{4}\right)$ ).

nucleophiles have already been well studied, ${ }^{[21]}$ we focused on carbon nucleophiles. To the best of our knowledge intermolecular ${ }^{[22]}$ hydroarylation of ynamides had only been reported with indole derivatives. ${ }^{[23]}$ Therefore, we decided to test the hydroarylation with electron-rich trimethoxybenzene 4. To our delight, the expected adduct $5 \mathrm{a}$ was obtained with $41 \%$ yield as a single Z-isomer after $20 \mathrm{~h}$ of reaction at $40{ }^{\circ} \mathrm{C}$ (Scheme 4 , condition A). Alternatively, it was also found that $\left[\operatorname{RuCl}_{2}(\mathrm{CO})_{3}\right]_{2}$ in association with a silver salt (condition $B)^{[24]}$ performed better, since no thermal activation was required. In this case, $\mathbf{5 a}$ was equally isolated as a single isomer. This transformation is interesting, not only because it represents a straightforward access to hindered and functionalized styrene derivatives but also

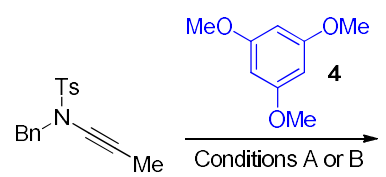

1a

Conditions A: $\quad \mathrm{Znl}_{2}(5 \mathrm{~mol} \%)$,

$\mathrm{DCM}, 40^{\circ} \mathrm{C}, 20 \mathrm{~h}$

Conditions B: $\left.\quad \mathrm{RuCl}_{2}(\mathrm{CO})_{3}\right]_{2}(5 \mathrm{~mol} \%), \mathrm{AgSbF}$

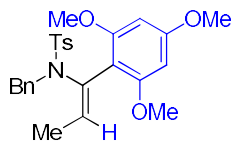

$5 a$

$41 \%(E / Z>1: 50)$

$56 \%(E / Z>1: 50)$

Scheme 4. Hydroarylation of ynamides. 
because it indicates clearly that the role of the $\mathrm{Znl}_{2}$ catalyst is the activation of the ynamide partner.

\section{Conclusions}

In summary, among different catalytic systems tested, including transition metal-based catalysts and Lewis acids, we found that $\mathrm{Znl}_{2}$ was able to efficiently catalyze the syn hydroalkoxylation of internal ynamides with 1,3-diones. Advantageously, this transformation could be performed in various solvents. In a general manner, reactions proceeded smoothly at room temperature giving the adducts in good yields and as $E$-isomers exclusively. As shown by the scope investigation, various functional groups either on the ynamides or the 1,3-diones were well tolerated. This transformation was successfully transposed to the hydroarylation of ynamide with an electron-rich arene. This result seems to indicate that $\mathrm{ZnI}_{2}$ activates the ynamides to trigger the hydroalkoxylation. Further studies on the reaction mechanism and the reactivity of adducts are currently undergoing in our laboratory.

\section{Experimental Section}

General procedure for the addition of 1,3-diones to terminal ynamides: In a $5 \mathrm{~mL}$ Schlenk flask under nitrogen were added in turn Znl2 ( $8.0 \mathrm{mg}, 0.0125 \mathrm{mmol}, 5 \mathrm{~mol} \%$ ), the ynamide $(0.5 \mathrm{mmol}, 1$ equiv.), $1,3-$ diketone derivatives $(0.5 \mathrm{mmol}, 1$ equiv. $)$ and DCM $(3 \mathrm{~mL})$. The reaction mixture was allowed to stir at 25 or $40{ }^{\circ} \mathrm{C}$ for the indicated reaction time. Volatiles were removed under reduced pressure and the crude residue was purified by silica gel flash chromatography using petroleum ether and ethyl acetate as eluent to give the pure desired product.

\section{Acknowledgements ((optional))}

This work was supported by the Ministère de l'enseignement supérieur et de la recherche (L.G. Ph.D. grant), ECM (R.P. ATER grant), AMU and the CNRS. We thank Dr. Christophe Chendo and Dr. Valérie Monnier for mass spectrometry analyses (Spectropole, Fédération des Sciences Chimiques de Marseille). We acknowledge Dr. Julie Broggi for useful comments on this manuscript.

Keywords: Hydroalkoxylation $•$ Ynamide $・ 1,3$-Dione $・$ Lewis acid $•$ Enamine

[1] a) G. Evano, C.Theunissen, M. Lecomte, Aldrichimica Acta 2015, 48, 59-70; b) X.-N. Wang, H.-S. Yeom, L.-C. Fang, S. He, Z.-X. Ma, B. L. Kedrowski, R. P. Hsung, Acc. Chem. Res. 2014, 47, 560-578; c), K. A DeKorver, H. Li, A. G. Lohse, R. Hayashi, Z. Lu, Y. Zhang, R. P. Hsung Chem. Rev. 2010, 110, 5064-5106; d) G. Evano, A. Coste, K. Jouvin Angew. Chem. 2010, 122, 2902-2921; Angew. Chem. Int. Ed. 2010, 49 2840-2859; e) C. A. Zificsak, J. A. Mulder, R. P. Hsung, C. Rameshkumar, L.-L. Wei, Tetrahedron 2001, 57, 7575-7606.

[2] For selected references of oxidation, see: a) F. Pan, X.-L. Li, X.-M. Chen, C. Shu, P.-P. Ruan, C.-H. Shen, X. Lu, L.-W. Ye, ACS Catal. 2016, 6 6055-6062; b) H. Huang, L. Tang, Q. Liu, Y. Xi, G. He, H. Zhu, Chem. Commun. 2016, 52, 5605-5608; c) L. Li, C. Shu, B. Zhou, Y.-F. Yu, X.-Y.
Xiao, L.-W. Ye, Chem. Sci. 2014, 5, 4057-4064; d) F. Pan, S. Liu, C. Shu, R.-K. Lin, Y.-F. Yu, J.-M. Zhou, L.-W. Ye, Chem. Commun. 2014, 50 10726-10729; e) C.-H. Shen, L. Li, W. Zhang, S. Liu, C. Shu, Y.-E. Xie, Y.-F. Yu, L.-W. Ye, J. Org. Chem. 2014, 79, 9313-9318; f) L.-Q. Yang K.-B. Wang, C.-Y. Li, Eur. J. Org. Chem. 2013, 2775-2779; g) Y. Minko, M. Pasco, L. Lercher, M. Botoshansky, I. Marek, Nature 2012, 490, 522 526; h) R. B. Dateer, K. Pati, R.-S. Liu, Chem. Commun. 2012, 48, 7200 7202; i) P. W. Davies, A. Cremonesi, N. Martin, Chem. Commun. 2011 47, 379-381; j) C.-F. Xu, M. Xu, Y.-X. Jia, C.-Y. Li, Org. Lett. 2011, 13 1556-1559; k) A. Mukherjee, R. B. Dateer, R. Chaudhuri, S. Bhunia, S. N. Karad, R.-S. Liu, J. Am. Chem. Soc. 2011, 133, 15372-15375; I) Z. F. Al-Rashid, W. L. Johnson, R. P. Hsung, Y. Wei, P.-Y. Yao, R. Liu, K. Zhao, J. Org. Chem. 2008, 73, 8780-8784.

[3] For selected references of reactions involving an oxetene formation, see: a) L. You, Z. F. Al-Rashid, R. Figueroa, S. K. Ghosh, G. Li, T. Lu, R. P. Hsung, Synlett 2007, 1656-1662; b) K. C. M. Kurtz, R. P. Hsung, Y. Zhang, Org. Lett. 2006, 8, 231-234.

[4] For other relevant transformations, see: a) H. Liu, Y. Yang, J. Wu, X.-N Wang, J. Chang, Chem. Commun. 2016, 52, 6801-6804; L. Chen, Y.-M. Cui, Z. Xu, J. Cao, Z.-J. Zheng, L.-W. Xu Chem. Commun. 2016, 52, 11131-11134; c) S. Bhunia, C.-J. Chang, R.-S. Liu, Org. Lett. 2012, 14, 5522-5525; d) J. Oppenheimer, W. L. Johnson, M. R. Tracey, R. P. Hsung, P.-Y. Yao, R. Liu, K. Zhao, Org. Lett. 2007, 9, 2361-2364

[5] a) H. Huang, L. Tang, Y. Xi, G. He, H. Zhu, Tetrahedron Lett. 2016, 57, 1873-1876; b) S. Xu, J. Liu, D. Hu, X. Bi; Green Chem. 2015, 17, 184 187; c) N. Ghosh, S. Nayak, A. K. Sahoo, Chem. Eur. J. 2013, 19, 9428 9433; d) G. Compain, K. Jouvin, A. Martin-Mingot, G. Evano, J. Marrot S. Thibaudeau, Chem. Commun. 2012, 48, 5196-5198; e) X. Jin, K Yamaguchi, N. Mizuno, Chem. Lett. 2012, 41, 866-867.

[6] S. Kramer, J. L. H. Madsen, M. Rottländer, T. Skrydstrup, Org. Lett 2010, 12, 2758-2761.

[7] D. L. Smith, W. R. F. Goundry, H. W. Lam, Chem. Commun. 2012, 48 1505-1507.

[8] a) A. M. Cook, C. Wolf, Angew. Chem. 2016, 128, 2982-2986; Angew. Chem. Int. Ed. 2016, 55, 2929-2933; b) L. Hu, S. Xu, Z. Zhao, Y. Yang Z. Peng, M. Yang, C. Wang, J. Zhao, J. Am. Chem. Soc. 2016, 138, 13135-13138

[9] B. Peng, X. Huang, L.-G. Xie, N. Maulide, Angew. Chem. 2014, 126, 8718-8721; Angew. Chem. Int. Ed. 2014, 53, 8718-8721.

[10] During the preparation of the manuscript, it was reported a trans addition of $\mathrm{MeOH}$ to ynamides as a side reaction of palladium-catalysed reduction of ynamide using $\mathrm{EtOH}$ as hydrogenating agent: A. Siva Reddy, K. C. K. Swamy, Angew. Chem. 2017, 129, 7088-7092; Angew. Chem. Int. Ed. 2017, 56, 6984-6988.

[11] a) J. A. Mulder, R. P. Hsung, M. O. Frederick, M. R. Tracey, C. A Zificsak, Org. Lett. 2002, 4, 1383-1386; b) N. P. Grimster, D. A. A. Wilton, L. K. M. Chan, C. R.A. Godfrey, C. Green, D. R. Owen, M. J. Gaunt, Tetrahedron 2010, 66, 6429-6436.

[12] a) M. O. Frederick, R. P. Hsung, R. H. Lambeth, J. A. Mulder, M. R Tracey, Org. Lett. 2003, 5, 2663-2666; b) K. C. M. Kurtz, M. O. Frederick R. H. Lambeth, J. A. Mulder, M. R. Tracey, R. P. Hsung, Tetrahedron 2006, 62, 3928-3938.

[13] For early reports with ynamines, see: a) J. Ficini, C. Barbara Tetrahedron Lett. 1966, 7, 6425-6429; b) J. Ficini, N. Lumbroso-Bader J. Pouliquen, Tetrahedron Lett. 1968, 9, 4139-4142;

[14] A. Siva Reddy, A. L. S. Kumari, S. Saha, K. C. K. Swamy, Adv. Synth Catal. 2016, 358, 1625-1638.

[15] a) H. Clavier, A. Lepronier, N. Bengobesse-Mintsa, D. Gatineau, H. Pellissier, L. Giordano, A. Tenaglia, G. Buono, Adv. Synth. Catal. 2013 355, 403-408; b) H. Clavier, G. Buono, Chem. Rec. 2017, 17, 399-414.

[16] L. V. Graux, H. Clavier, G. Buono, ChemCatChem 2014, 6, 2544-2548.

[17] P. Starkov, J. T. Moore, D. C. Duquette, B. M. Stoltz, I. Marek, J. Am. Chem. Soc. 2017, 139, 9615-9620.

[18] For an example of Au-catalyzed isomerization of enamides, see: $M$ Sriram, Y. Zhu, A. M. Camp, C. S. Day, A. C. Jones, Organometallics 2014, 33, 4157-4164. 
[19] For selected examples, see: L. Chen, L. Yu, Y. Deng, Y. Cui, G. Bian, J. Cao, Org. Biomol. Chem. 2016, 14, 564-569 and references 2a and 10b.

[20] For further details, see the supporting information.

[21] For selected examples, see: a) H. Huang, L. Tang, X. Han, G. He, Y. Xi, H. Zhu, Chem. Commun. 2016, 52, 4321-4324; b) C. Shu, C.-H. Shen Y.-H. Wang, L. Li, T. Li, X. Lu, L.-W. Ye, Org. Lett. 2016, 18, 4630-4633 c) Z. Chen, J. Huang, Z. Wang, J. Org. Chem. 2016, 81, 9308-9314; d) Y. Wu, L. Zhu, Y. Yu, X. Luo, X. Huang, J. Org. Chem. 2015, 80, 1140711416 e) S. Kramer, K. Dooleweerdt, A. T. Lindhardt, M. Rottländer, T. Skrydstrup, Org. Lett. 2009, 11, 4208-4211; f) N. Shindoh, Y. Takemoto, K. Takasu, Chem. Eur. J. 2009, 15, 7026-7030.

[22] For an example of intramolecular hydroarylation, see: Y. Zhang, R. P. Hsung, X. Zhang, J. Huang, B. W. Slafer, A. Davis, Org. Lett. 2005, 7 1047-1050.
[23] a) Y. Zhang, Tetrahedron 2006, 62, 3917-3927; b) Y. Zhang Tetrahedron Lett. 2005, 46, 6483-6486.

[24] a) L. V. Graux, M. Giorgi, G. Buono, H. Clavier, Organometallics 2015 34, 1864-1871; for the pioneering work on the cycloisomerization of arenynes with $\left[\mathrm{RuCl}_{2}(\mathrm{CO})_{3}\right]_{2}$, see: b) N. Chatani, H. Inoue, T. Ikeda, S. Murai, J. Org. Chem. 2000, 65, 4913-4918.

[25] G. R. Fulmer, A. J. M. Miller, N. H. Sherden, H. E. Gottlieb, A. Nudelman B. M. Stoltz, J. E. Bercaw, K. I. Golberg, Organometallics 2010, 29, 2176 2179 
Entry for the Table of Contents (Please choose one layout)

Layout 1:

\section{COMMUNICATION}

Text for Table of Contents

*one or two words that highlight the emphasis of the paper or the field of the study

((Insert TOC Graphic here: max. width: $5.5 \mathrm{~cm}$; max. height: $5.0 \mathrm{~cm}$; NOTE: the final letter height should not be less than $2 \mathrm{~mm}$.))

\section{Key Topic*}

Author(s), Corresponding Author(s)*

Page No. - Page No.

Title

Layout 2:

\section{COMMUNICATION}

EWG<smiles>[R]N(CC)NC#C</smiles><smiles>O=C1CC(=O)CC(=O)C1</smiles>

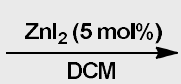

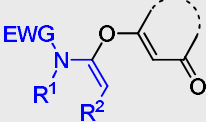

17 examples

Only E isomers

The hydroalkoxylation of internal ynamides with 1,3-diones was achieved in a highly syn manner using zinc iodide as Lewis acid catalyst. The scope of this transformation was found broad and compatible with various functional groups.

\section{Ynamides*}

Rémi Plamont, Lionel. V. Graux, Hervé Clavier*

Page No. - Page No.

Highly selective syn addition of 1,3diones to internal ynamides catalyzed by zinc iodide 